\title{
Analysis on Effective Management Ways of College Students' Sports Event Volunteers in Colleges and Universities
}

\author{
Yanbin Li \\ School of Physical Education, Linyi University, Linyi, 276000, China
}

Keywords: Colleges and universities. College students. Sports events. Volunteers. Efficient managements

\begin{abstract}
As the rapid development of our sport industry, big sports events are held more and more where huge number of high quality volunteers is required to make sure the sports event can be operated properly. As the there are great resources of human, materials and equipments, colleges and universities have become important volunteers providers. Therefore, management of college students' sports events volunteers shall be enhanced to assure the service quality. Significance and implementation ways of efficient management on college students' sport events volunteers would be analyzed in this article.
\end{abstract}

\section{Overview of College Students' Sports Event Volunteers Management in Colleges and Universities}

\section{Awareness of College Students' Sports Event Volunteers}

Volunteers of college students' sports event are enrolled college students approved by event organizers, and co-recruited and managed by schools to coordinate the event organization in order to offer services to a spot event. The recruit requirements are made by event organizers, and implemented by colleges and universities with responsibilities of selection and registration. The students selected shall be under the charge of event organizers and colleges and universities. Generally, college students who volunteered would not be paid in the principle of voluntaries would sacrifice their time and energy to ensure the event to run orderly. Furthermore, the volunteers of college students' sports event shall have extreme passion and plenty time to blend in Olympic sprits with required professional service techniques.

\section{Features of Volunteers Management in Colleges and Universities Sports Event}

Compared to social voluntary organization, the features of volunteers' management in colleges and universities sports event are as following: 1). Management organized by students of the youth league to recruitment, selection, training, daily management and assessment; strong organization, discipline and harmony could be applied in management; 2). Temporary could be shown in volunteers management as big sports events would not be held frequently or in a long term; 3). Unified management shall be conducted by colleges and universities for volunteers in college students' sports event to increase management rate substantially and make the collection regularization; at the same time, the method and pattern of management could be improved in real time and be more scientific.

\section{Volunteer Management Content of Sports Events in Colleges and Universities}

Generally speaking, administrative order pattern used as the management method implanted in colleges and universities make the volunteers in passive position, they can only accept the work assigned by organizers without the right or with limited space to choose the work type. Main points of volunteer management in colleges and universities for sports events can be shown as following: 1). Recruitment and selection. Colleges and universities are responsible for recruitment information published, selection criteria made and relevant position arrangement; 2). Training program for volunteers. Volunteers shall be helped to adapt to the working environment by training program. They get to know what the responsibilities they have and what kind of knowledge and techniques are required in relevant services, and then team work ability shall be enhanced. 3). Daily management for volunteers. Colleges and universities shall manage the status of working, psychology and life of 
volunteers during the services time; 4). Guarantees for volunteers. Stimulus measures would be formulated in exam results and class attendances to encourage college students' participation in voluntary services and improve the quality of voluntary services; 5). Incentive assessment for volunteers. Colleges and universities would like to assess volunteers' attendance rate, service quality, service duration and team sprits to award material rewards and spiritual rewards on the basis of the assessment results.

\section{Significance of Efficiency Management of Volunteers of Sports Event in College and Universities}

\section{Benefits for promotion of volunteers' self-development}

The volunteers of college students' sports event would have rich experiences to help them adapt to the social environment rapidly, and they can get in touch with social knowledge that could not be learnt in classes, which has important meanings in promotion comprehensive development of college student volunteer. This could be shown specifically in the following: 1). Benefits for horizon enrichment with knowledge addition. As various services would be offered in the sport event, including language translation, site setting-up, logistic and first aid etc. college students could experience more and powerful advantages for new knowledge and new technology could be provided. 2). Benefits for social communication ability development. During the services, college students shall to communicate with different organizations, social groups and other volunteers. With the help of communication and exchanges, mutual promotion and learning will be conducted to offer a better service for sports events. Therefore, the social communication space could be enlarged and the ability could be enforced. 3). Benefits for positive outlook on life and value formulation. The sense of self-improvement, self-study, and self-education of college students could be promoted by participating in sports event, make the students affected by Olympic sprits and enhance the moral realm and mental shackles, and to set foundation for college students to affirm their ideas and beliefs and realize the value of life.

Benefits for competitiveness and development improvement of colleges and universities

The development of colleges and universities can affect directly the qualities of college students. By participating in voluntary activities of big sports events, effective management could be implemented to college student volunteers, which could increase their various abilities, promote their comprehensive development, and have significant influence on competitiveness and development improvement. Meanwhile, colleges and universities could public their good images to society with the help of big sports events, to demonstrate their elegant appearance, and to gain more popularity. This would help a lot in enrollment enrichment and graduates' competitiveness enhancement, as well as in foundation laid for prestigious university construction in colleges and universities.

\section{Benefits for sound development of volunteers' voluntary career}

Essentially, to get a long-term development of voluntary career, both of its own functions and supports of all volunteers are need. Efficient management plays an irreplaceable role in sports event volunteers' the voluntary career promotion. On one hand, by managing the college student volunteers, the function voluntary career could be fully displayed, including social integration and functions of guarantee, economic and political. All volunteers in colleges and universities are college students and they are managed object, while the teaching and administrative staff is managers. This relationship of managing and being managed ensured functions of voluntary career to be implemented. On the other hand, with the management of college student volunteers, positive energy shall be stimulated continuously during process of voluntary activities to show their value of life, and good foundations could be constructed in various voluntary activities to promote voluntary careers development. 


\section{Effective Management Ways of College Students' Sports Event Volunteers in Colleges and Universities}

\section{Human-based Management Implementation}

Facts proved that the most effective way to promote the management efficiency on human-based management. Therefore, with the management of volunteers in colleges and universities sports events, human-based management could be implemented to reduce peremptory norm, and then the real meaning of volunteerism could be shown. Firstly, during the selection of volunteers, not only the capacity evaluation shall be emphasized, but the participation motivation shall be serious inspected as the basis of selection. Secondly, detailed work introduction shall be done properly for training program to master actual working contents and prepare for successful completion of the voluntary work. Thirdly, during competition, the hardest working period of volunteers, so the willpower of them might be changed and have the feeling of giving up. In order to avoid this situation from happening, psychological counseling and dredge of volunteers shall be done in a timely manner to make sure that they can finish the job in the end. Lastly, reasonable contingency plan formulated to deal with all kinds of emergencies, and spare volunteers shall be reserved to assure the work proceeds normally.

\section{Enforce the training program and improve the services level}

Training of college students sports event volunteers is an important part of volunteer management, which is directly link to the services level and quality. To this end, colleges and universities shall enhance the volunteers' training and improve the service awareness and techniques from various aspects and different levels. First of all, correct service philosophy shall be established. Volunteers shall take correct understanding of essential and contents of voluntary activities, and with dissolving the incorrect understanding, the work objectives like service the society and help others shall be comprehended without the aim of being paid. In the mean time, volunteers shall be fully aware of his value, and then he would like to be involved in voluntary activities. Secondly, enhance the motivation of service. Volunteers shall be conducted to formulate correct values with permeation of service concept during the management procedure, and made to love the work from deeply of their heart, and then the service motivation could be enhanced. Thirdly, strengthen the service techniques training. Professional volunteers' training center shall be established in colleges and universities, experience college students or teachers shall be invited to conduct training process, which could focus on professional techniques, services concept, outer image and comprehensive capability. Simulated training could be introduced to practice to simulate the learning interests of volunteers.

\section{Performance Assessment Management Improvement}

Performance assessment shall be conducted for sports event volunteers, which could achieve self-management and self-motivate, so a further implementation of work could be improved. The following aspects could be taken into consideration by colleges and universities to develop a performance assessment management: 1). Special assessment group established. The main responsibility of this group is to formulate the standards of assessment and register in accordance with volunteer's performance, enact workable assessment procedure and apply scientific assessing method to conduct assessment.; 2). Assessment standards formulation. During the specific formulation process, systematic analysis shall be conducted by qualitative and quantitative, and take index as references like accomplish of work, work attitude, attendance rate and satisfactory of service objectives. 3). Assessment method shall be used flexibly. As the number of people involved in sports event is large, various assessment methods shall be applied with different types of work more targeted, such as questionnaire, observation, and interview. In addition, because the assessment can only be conducted in accordance with events, the on site assessment shall be carried out properly. At the same time, the results of assessment shall be published in time to make volunteers aware the insufficient in the work and improve it; in this way, the service level could be enhanced. 5). Link the assessment results to volunteers' reward. Double rewards including spiritual and materials could be awarded to excellent volunteers, like certificate, bonus, titles etc. 


\section{Incentive System Perfection}

Colleges and universities shall establish sound college students sports event volunteers incentive system to motivate the volunteers management work carried out orderly. Firstly, colleges and universities could refer to overseas management experience to combine the voluntary activates with joining the party, entering a higher school and career to make the sports event volunteers respect and accepted by the society, so that much more passion could be conducted into voluntary services. Secondly, recognition awards system shall be established. Colleges and universities shall award properly honor and rewards to volunteers based on their performance in the events. Usually, internal excitation that from the intrinsic reward after volunteer's participation is the feeling of pride and glory of being a volunteer, he is happy to presenting himself in this way; while external motivation is satisfaction gained by commended, encouragement and accepted. Powerful working passion could be shown with the combination of the two. Thirdly, integrates humanistic care with incentive system. No matter what kind of incentive measures to be taken, the care shall be highlighted. In another word, the humanistic care shall be integrated into incentive system, and this is the main power of retaining volunteers. At the same time, create a harmonious, democratic and active atmosphere as far as possible, to motivate the volunteers' morale, simulate their participation and increase the satisfaction. All these could help improve the management efficiency. Creation of a good organization atmosphere requires the endeavor of managers and all volunteers. Only with the close cooperation, can the goal be achieved.

\section{Conclusion}

In a word, efficiency management of students' sports event volunteers in colleges and universities have significant meanings in improving the self-development of college students, increasing the competitiveness of colleges and universities and promoting steady development of voluntary career. Colleges and universities shall adopt scientific management methods, with the help of human-based management, volunteers training enforcement, performance assessment system and incentive system improvement, to increase management level and ensure the volunteers could offer high quality voluntary services to sports events.

\section{References}

[1] Chen Shuai: Study on Management of National College Students' Sports Event Programs [D], Northeast Normal University, 2012.

[2] Lu Qin: Study on Long-term Mechanism of College Students' Voluntary Activities, Party Construction in School and Ideological Education, 2010 (4).

[3] Hou Lei: Study on Voluntary Activities Conducted by College Student Volunteers [D], East China Normal University, 2009.

[4] Zhang Xing, Pu Chuanxin: Five Pillars of Self-management Undergraduate Athletes, Journal of Beijing Sport University, 2008 (4).

[5] Zhang Hui: Study on Development Issues of College Students Voluntary Organization [D],Shandong University, 2011 (3).

[6] Shen Mingju: Study on Issues and Solutions to Existing College Students Voluntary Activities [D], East China Normal University, 2010.

[7] Miao Miao: Study on Sports Event Service Risk Management of College Students Volunteers [D], Shanxi University, 2012. 